\title{
Acid incubation reverses the polarity of intercalated cell transporters, an effect mediated by hensin
}

\author{
George J. Schwartz, ${ }^{1}$ Shuichi Tsuruoka, ${ }^{2}$ Soundarapandian Vijayakumar, ${ }^{3}$ \\ Snezana Petrovic, ${ }^{1}$ Ayesa Mian, ${ }^{1}$ and Qais Al-Awqati ${ }^{3}$ \\ ${ }^{1}$ Department of Pediatrics and Strong Children's Research Center, University of Rochester School of Medicine, \\ Rochester, New York, USA \\ ${ }^{2}$ Department of Clinical Pharmacology, Jichi Medical School, Minamikawachi, Tochigi, Japan \\ ${ }^{3}$ Department of Medicine and Physiology, College of Physicians and Surgeons of Columbia University, \\ New York, New York, USA \\ Address correspondence to: George J. Schwartz, Division of Nephrology, Box 777, University of Rochester \\ School of Medicine, 601 Elmwood Avenue, Rochester, New York 14642, USA. \\ Phone: (716) 275-9784; Fax: (716) 756-8054; E-mail: George_Schwartz@urmc.rochester.edu.
}

Received for publication May 17, 2001, and accepted in revised form November 12, 2001.

\begin{abstract}
Metabolic acidosis causes a reversal of polarity of $\mathrm{HCO}_{3}{ }^{-}$flux in the cortical collecting duct (CCD). In CCDs incubated in vitro in acid media, $\beta$-intercalated $\left(\mathrm{HCO}_{3}{ }^{-}\right.$-secreting) cells are remodeled to functionally resemble $\alpha$-intercalated $\left(\mathrm{H}^{+}\right.$-secreting) cells. A similar remodeling of $\beta$-intercalated cells, in which the polarity of $\mathrm{H}^{+}$pumps and $\mathrm{Cl}^{-} / \mathrm{HCO}_{3}{ }^{-}$exchangers is reversed, occurs in cell culture and requires the deposition of polymerized hensin in the ECM. CCDs maintained $3 \mathrm{~h}$ at low pH ex vivo display a reversal of $\mathrm{HCO}_{3}{ }^{-}$flux that is quantitatively similar to an effect previously observed in acidtreated rabbits in vivo. We followed intracellular $\mathrm{pH}$ in the same $\beta$-intercalated cells before and after acid incubation and found that apical $\mathrm{Cl} / \mathrm{HCO}_{3}$ exchange was abolished following acid incubation. Some cells also developed basolateral $\mathrm{Cl}^{-} / \mathrm{HCO}_{3}{ }^{-}$exchange, indicating a reversal of intercalated cell polarity. This adaptation required intact microtubules and microfilaments, as well as new protein synthesis, and was associated with decreased size of the apical surface of $\beta$-intercalated cells. Addition of anti-hensin antibodies prevented the acid-induced changes in apical and basolateral $\mathrm{Cl}^{-} / \mathrm{HCO}_{3}{ }^{-}$exchange observed in the same cells and the corresponding suppression of $\mathrm{HCO}_{3}{ }^{-}$secretion. Acid loading also promoted hensin deposition in the ECM underneath adapting $\beta$-intercalated cells. Hence, the adaptive conversion of $\beta$-intercalated cells to $\alpha$-intercalated cells during acid incubation depends upon ECM-associated hensin.
\end{abstract}

J. Clin. Invest. 109:89-99 (2002). DOI:10.1172/JCI200213292.

\section{Introduction}

The cortical collecting duct (CCD) of the kidney is comprised of principal cells, involved in salt, water, and potassium transport, and intercalated cells, which make up a third of the cells in this segment and mediate acid-base transport $(1,2)$. Two functionally distinct subtypes of intercalated cells have been identified in the CCD: one secretes $\mathrm{HCO}_{3}{ }^{-}$and the other absorbs it (3-5). Reabsorption of $\mathrm{HCO}_{3}^{-}$(i.e., secretion of protons) is accomplished in $\alpha$-intercalated cells by an apical $\mathrm{H}^{+}$-ATPase and a basolateral $\mathrm{Cl}^{-} / \mathrm{HCO}_{3}{ }^{-}$exchanger $(4,6-8)$. Secretion of $\mathrm{HCO}_{3}{ }^{-}$by $\beta$-intercalated cells is mediated by the same kinds of transporters but located on the opposite cell membranes $(4,8-10)$.

The CCD plays an important role in acid base homeostasis, especially in the corrective response to an acid or alkali load. In rabbits, CCDs generally secrete $\mathrm{HCO}_{3}{ }^{-}$ $(4,5,11,12)$, but metabolic acidosis causes this segment to absorb $\mathrm{HCO}_{3}^{-}(4,5,11,13)$. We initially found that acid feeding increased the number of $\alpha$ cells and decreased the number of $\beta$ cells without changing the total number of intercalated cells, and hence we concluded that $\beta$ cells converted to $\alpha$ cells; we termed this process plasticity of functional epithelial polarity (4). The reversal of polarity of $\mathrm{HCO}_{3}^{-}$flux is of obvious physiological interest, and understanding the cellular mechanisms by which the functional proteins change their targeting paths raises several questions of great importance to cell biology. Since our original description, several molecular tools have become available to characterize intercalated cells. For example, CCDs were shown to contain some cells with apical $\mathrm{H}^{+}$-ATPase and others with basolateral localization $(7,8)$. In addition, there was a large fraction of intercalated cells in which the pattern of staining was more intracellular than restricted to polarized membrane domains $(7,9,14)$. The situation with the apical and basolateral anion exchangers is much more complex (15), but there is now general agreement for the existence of several subtypes of intercalated cells. The central question of whether an individual $\beta$ cell can convert to an $\alpha$ cell awaited the development of methods that allow the examination of the same cell in response to acid treatment. Here, we provide such evidence.

Recently, we developed a model of metabolic acidosis in vitro by which the CCD reverses the polarity of net 
$\mathrm{HCO}_{3}{ }^{-}$flux after 3 hours of incubation at low $\mathrm{pH}(5)$. These studies revealed that in vitro exposure to acid media induced extensive remodeling of $\beta$-intercalated cells, especially apical membrane components; much of this process was mediated by apical endocytosis. In addition, acid incubation resulted in decreased $\mathrm{HCO}_{3}{ }^{-}$ secretion, a process that required de novo protein and RNA synthesis and the integrity of the cytoskeleton (16). More recently, we showed that the CCD adapts to low $\mathrm{pH}$ in vitro by downregulating $\mathrm{HCO}_{3}{ }^{-}$secretion in $\beta$-intercalated cells and upregulating $\mathrm{HCO}_{3}{ }^{-}$absorption in $\alpha$-intercalated cells (3). These studies opened the way for examining the response of the same identified $\beta$ cells to an acid load in a situation as close to the in situ situation as possible.

To investigate the biochemical and molecular basis for plasticity of epithelia, we generated an immortalized cell line of $\beta$-intercalated cells that exhibited apical $\mathrm{Cl}^{-} / \mathrm{HCO}_{3}{ }^{-}$exchange and basolateral $\mathrm{H}^{+}$-ATPase activities (17). This phenotype was reproduced when the cells were seeded at subconfluent density and examined when they formed an epithelial monolayer capable of transepithelial $\mathrm{HCO}_{3}{ }^{-}$transport. When they were plated at high density, they converted to an $\alpha$-like form with an apical $\mathrm{H}^{+}$-ATPase and a basolateral $\mathrm{Cl}^{-} / \mathrm{HCO}_{3}{ }^{-}$ exchanger. A new protein, termed hensin, was deposited in the ECM of these high-density cells, but not in the matrix of cells plated at low density. When hensin was purified from the ECM, it was capable of converting the low-density cells (i.e., $\beta$-like cells) to $\alpha$-like phenotype. While soluble hensin is also secreted by low-density cells, only high-density cells localize it to the ECM (18). Furthermore, only the polymeric ECM form of hensin is capable of inducing this reversal of functional polarity in the cell line (18). Hensin is expressed in most epithelial cells, but in the kidney it is found only in collecting tubules where it is expressed by both principal and intercalated cells (19). The remarkable conversion of one phenotype to another in response to seeding density suggested that the pathways thus identified might share a common component with CCDs that adapt to acid treatment.

In this paper we demonstrate that the same identified $\beta$-intercalated cells convert to $\alpha$-like cells and that this process is associated with deposition of hensin in the ECM of these cells but not in that of other cells. Moreover, Ab's to hensin prevent this conversion of polarity. We conclude that the polarity reversal of intercalated cells in the CCD occurs by a hensin-mediated pathway.

\section{Methods}

Animals. Female New Zealand white rabbits weighing $1.5-2.8 \mathrm{~kg}$ were maintained on laboratory chow and water (3). Acid treatment in vivo was accomplished by providing $75 \mathrm{mM} \mathrm{NH}_{4} \mathrm{Cl}$ in $5 \%$ sucrose drinking solution and limiting food intake to $2 \%$ of body weight (20).

Microperfusion of CCDs. CCDs were microdissected and microperfused as performed in this laboratory $(3,20$, 21). Equilibration, transport, and cell $\mathrm{pH}$ studies were performed using Burg's solution in the perfusate and bath, containing (in mM) $120 \mathrm{NaCl}, 25 \mathrm{NaHCO}_{3}, 2.5$ $\mathrm{K}_{2} \mathrm{HPO}_{4}, 2 \mathrm{CaCl}_{2}, 1.2 \mathrm{MgSO}_{4}, 5.5$ D-glucose, 1 trisodium citrate, 4 sodium lactate, and 6 L-alanine, $290 \pm 2$ $\mathrm{mOsm} / \mathrm{kg} \mathrm{H}_{2} \mathrm{O}$ and gassed with $94 \% \mathrm{O}_{2}-6 \% \mathrm{CO}_{2}$, yielding a $\mathrm{pH} 7.4$ at $37^{\circ} \mathrm{C}(3,5,20)$. The bath was continually exchanged, except when precious $A b$ 's were used during 3-hour incubations; in those cases, osmolality was maintained within $\pm 1 \%$ by adding $240 \mu \mathrm{l}$ water per hour (22) and replacing the bath and Ab's each hour. Incubations for 3 hours in acid ( $\mathrm{pH} 6.8$ in both luminal and bathing solutions) and control ( $\mathrm{pH} 7.4)$ media were described previously $(3,16,20,23)$; incubation at $\mathrm{pH} 6.8$ yields a physiology comparable to 3 days of acidosis in vivo, while that at $\mathrm{pH} 7.4$ sustains net $\mathrm{HCO}_{3}{ }^{-}$secretion.

Anti-hensin $A b$ 's. Hensin was first purified as a new 230-kDa ECM protein produced by rabbit intercalated cells in vitro (24), and a partial cDNA allowed us to produce in Escherichia coli a 32-kDa fusion protein composed of SRCR domains 6 and 7, which was used to generate the polyclonal Ab's. These antisera recognized hensin as a native secreted protein by immunoprecipitation, denatured on Western blots, in fixed and permeabilized cells and kidney sections (19) and in nonfixed cells in culture (25). These Ab's also prevented all the hensin-mediated functions, such as the development of apical endocytosis, the induction of specific apical proteins (cytokeratin 19 and villin), the formation of the apical terminal web, and the change in cell shape. Ab's against other extracellular matrix proteins were obtained from commercial suppliers.

Bicarbonate transport. Triplicate collections of 12-15 $\mathrm{nl}$ of tubular fluid were made under water-saturated mineral oil and analyzed for $\mathrm{HCO}_{3}^{-}(3,20,21)$. When $\mathrm{J}_{\mathrm{HCO}}$ is greater than 0 , there is net $\mathrm{HCO}_{3}{ }^{-}$absorption; when $\mathrm{J}_{\mathrm{HCO}}$ is less than 0 , there is net $\mathrm{HCO}_{3}{ }^{-}$secretion. Measurements were repeated after the 3-hour incubation and compared with preincubation values. In ten of the $\mathrm{pH} 6.8$ incubations, guinea pig polyclonal $\mathrm{Ab}$ to rabbit hensin (1:100) (19), a comparable dilution of nonimmune guinea pig serum, or a mouse monoclon$\mathrm{al} \mathrm{Ab}$ to the ECM protein, collagen IV (Chemicon International, Temecula, California, USA), was added to the bath. In some studies, $5 \mu \mathrm{g}$ of the fusion protein were preincubated with $10 \mu \mathrm{l}$ of the serum for 1 hour at $4^{\circ} \mathrm{C}$, and the mixture was then added to $1 \mathrm{ml}$ of the $\mathrm{pH} 6.8$ incubation medium.

Cell pH studies. Cell $\mathrm{pH}$ was measured by excitation ratio fluorometry $(490 \mathrm{~nm} / 445 \mathrm{~nm}$ excitation; $520 \mathrm{~nm}$ emission) using 5-10 $\mu \mathrm{M}$ bis(carboxyethyl)carboxyfluorescein (BCECF; Molecular Probes Inc., Eugene, Oregon, USA) $(10,21)$. Fluorescence was detected in multiple intercalated cells and corrected for background (Photon Technology International Inc., Lawrenceville, New Jersey, USA). By examining cells in focus close to the perfusion pipette and in the wall of the tubule, movement and contaminating fluorescent signals were minimized. Readings were obtained in Burg's solution after the reversible removal of luminal $\mathrm{Cl}^{-}$and some- 
Table 1

$\mathrm{HCO}_{3}{ }^{-}$transport before and after 3-hour incubation at $\mathrm{pH} 6.8$

Nonimmune guinea pig serum or anti-collagen IV Ab

Before incubation

$\begin{array}{lcccc}P-\mathrm{HCO}_{3}{ }^{-} & \mathrm{C}-\mathrm{HCO}_{3}{ }^{-} & V_{\mathrm{c}} & J_{\mathrm{HCO} 3} & V_{\mathrm{t}} \\ 24.1 & 26.4 & 1.73 & -4.28 & -4.3 \\ 24.5 & 27.2 & 1.59 & -3.86 & -3.9 \\ 24.1 & 26.4 & 1.58 & -3.32 & -3.4 \\ 24.4 & 26.6 & 1.75 & -3.78 & -3.4 \\ 24.8 & 27.5 & 1.77 & -3.96 & -3.5 \\ 24.4 \pm 0.1 & 26.8 \pm 0.2 & 1.68 \pm 0.04 & -3.84 \pm 0.15 & -3.7 \pm 0.1\end{array}$

\begin{tabular}{ccccc}
\multicolumn{5}{c}{ After incubation } \\
$\mathrm{C}-\mathrm{HCO}_{3}{ }^{-}$ & $V_{\mathrm{c}}$ & $J_{\mathrm{HCO} 3}$ & $V_{\mathrm{t}}$ & $\Delta J_{\mathrm{HCO} 3}$ \\
21.7 & 1.60 & 4.27 & -3.3 & 8.55 \\
21.6 & 1.57 & 4.00 & -3.3 & 7.87 \\
21.4 & 1.57 & 3.76 & -3.0 & 7.08 \\
21.8 & 1.56 & 4.06 & -3.0 & 7.85 \\
21.9 & 1.62 & 3.87 & -3.0 & 7.82 \\
$21.7^{\mathrm{A}} \pm 0.1$ & $1.58 \pm 0.01$ & $3.99^{\mathrm{A}} \pm 0.09$ & $-3.1^{\mathrm{A}} \pm 0.1$ & $7.83 \pm 0.23$
\end{tabular}

Anti-hensin Ab

\begin{tabular}{lcccc}
\multicolumn{5}{c}{ Before incubation } \\
$\mathrm{P}-\mathrm{HCO}_{3}{ }^{-}$ & $\mathrm{C}-\mathrm{HCO}_{3}{ }^{-}$ & $V_{\mathrm{c}}$ & $J_{\mathrm{HCO} 3}$ & $V_{\mathrm{t}}$ \\
24.3 & 27.1 & 1.56 & -4.03 & -4.0 \\
24.4 & 26.8 & 1.68 & -4.51 & -4.3 \\
24.2 & 27.3 & 1.40 & -4.88 & -3.9 \\
24.9 & 26.6 & 1.75 & -2.76 & -3.9 \\
24.8 & 27.0 & 1.74 & -3.20 & -4.0 \\
$24.5 \pm 0.1$ & $27.0 \pm 0.1$ & $1.63 \pm 0.07$ & $-3.88 \pm 0.40$ & $-4.0 \pm 0.1$
\end{tabular}

$\mathrm{C}-\mathrm{HCO}_{3}^{-}$
24.2
24.5
24.4
24.8
25.0
$24.6^{\mathrm{A}, \mathrm{B}} \pm 0.2$

\begin{tabular}{cccc}
\multicolumn{4}{c}{ After incubation } \\
$V_{\mathrm{c}}$ & $J_{\mathrm{HCO} 3}$ & $V_{\mathrm{t}}$ & $\Delta J_{\mathrm{HCO} 3}$ \\
1.54 & 0.14 & -3.8 & 4.17 \\
1.65 & -0.15 & -4.0 & 4.36 \\
1.58 & -0.34 & -3.6 & 4.54 \\
1.57 & 0.12 & -3.8 & 2.88 \\
1.69 & -0.33 & -3.6 & 2.87 \\
$1.61 \pm 0.03$ & $-0.11^{\mathrm{A}, \mathrm{B}} \pm 0.10$ & $-3.8^{\mathrm{A}, \mathrm{B}} \pm 0.1$ & $3.76^{\mathrm{B}} \pm 0.37$
\end{tabular}

Anti-hensin Ab plus hensin fusion protein

\begin{tabular}{lcccccccccc}
\multicolumn{9}{c}{ Before incubation } & \multicolumn{4}{c}{ After incubation } \\
${\mathrm{P}-\mathrm{HCO}_{3}{ }^{-}}^{-}$ & $\mathrm{C}-\mathrm{HCO}_{3}{ }^{-}$ & $V_{\mathrm{c}}$ & $J_{\mathrm{HCO}}$ & $V_{\mathrm{t}}$ & $\mathrm{C}-\mathrm{HCO}_{3}{ }^{-}$ & $V_{\mathrm{c}}$ & $J_{\mathrm{HCO}}$ & $V_{\mathrm{t}}$ & $\Delta J_{\mathrm{HCO} 3}$ \\
24.2 & 26.0 & 1.67 & -3.84 & -3.3 & 22.1 & 1.57 & 3.95 & -2.5 & 7.79 \\
24.2 & 26.5 & 1.69 & -4.26 & -3.6 & 21.7 & 1.53 & 4.13 & -2.8 & 8.39 \\
24.3 & 25.8 & 1.46 & -3.2 & -3.0 & 22.5 & 1.60 & 4.01 & -2.4 & 7.21 \\
24.2 & 26.2 & 1.63 & -4.35 & -2.9 & 21.8 & 1.47 & 4.50 & -2.1 & 8.85 \\
$24.2 \pm 0.1$ & $26.1 \pm 0.1$ & $1.61 \pm 0.05$ & $-3.91 \pm 0.23$ & $-3.2 \pm 0.1$ & $22.0^{\mathrm{A}} \pm 0.2$ & $1.54 \pm 0.03$ & $4.15^{\mathrm{A}} \pm 0.11$ & $-2.5^{\mathrm{A}} \pm 0.1$ & $8.06^{\mathrm{A}} \pm 0.32$ \\
\hline
\end{tabular}

ASignificantly different from before incubation (paired $t$ test); ${ }^{\mathrm{B}}$ significantly different from non-immune serum (unpaired $t$ test). $P-\mathrm{HCO}_{3}{ }^{-}$, perfusate $\left[\mathrm{HCO}_{3}{ }^{-}\right]$ in $\mathrm{mEq} / \mathrm{l} ; \mathrm{C}_{-} \mathrm{HCO}_{3}{ }^{-}$, collected fluid $\left[\mathrm{HCO}_{3}{ }^{-}\right]$in $\mathrm{mEq} / \mathrm{l} ; V_{c}$, collection rate in nanoliters per minute; $J_{\mathrm{HCO}_{3}}$, net $\mathrm{HCO}_{3}{ }^{-}$flux in picomoles per minute per millimeter; $V_{\mathrm{t}}$, transepithelial voltage in $\mathrm{mV} ; \Delta \mathrm{HCO}_{\mathrm{HC}}$, change in $\mathrm{HCO}_{3}{ }^{-}$flux after incubation in $\mathrm{pmol} / \mathrm{min} / \mathrm{mm}$.

times after the reversible removal of basolateral $\mathrm{Cl}^{-}$. The sequence of readings was repeated in the same identified intercalated cells after 3 hours of incubation.

Agents were dissolved in $0.1 \%$ DMSO and added to the bathing solution 3-15 minutes before and during the 3-hour incubation at $\mathrm{pH}$ 6.8. These agents included $\mathrm{Ab}$ 's such as guinea pig anti-rabbit hensin polyclonal $\mathrm{Ab}$ (1:100 dilution) and nonimmune guinea pig serum (1:100, control for hensin $\mathrm{Ab})$, as well as the reagents colchicine $(10 \mu \mathrm{M})$, cytochalasin $\mathrm{D}(1 \mu \mathrm{M})$, anisomycin $(10 \mu \mathrm{M})$, and $\mathrm{O}, \mathrm{O}^{\prime}$-bis (2-aminophenyl) ethyleneglycol$\mathrm{N}, \mathrm{N}, \mathrm{N}^{\prime}, \mathrm{N}^{\prime}$-tetraacetic acid tetraacetoxymethylester (BAPTA-AM) $(10 \mu \mathrm{M}$; Molecular Probes Inc.).

$\beta$-intercalated cell cap length. Each CCD was perfused with FITC-peanut agglutinin (PNA; $20 \mu \mathrm{g} / \mathrm{ml}$, Vector Laboratories, Burlingame, California, USA) and monoclonal $\mathrm{Ab} \mathrm{B} 63,14 \mu \mathrm{g} / \mathrm{ml}$ (against the apical surface of $\beta$-intercalated cells) (26), followed by Texas red polyclonal goat anti-mouse secondary Ab (Jackson ImmunoResearch Laboratories, West Grove, Pennsylvania, USA). The CCD was then subjected to the 3 hour incubation, fixed in 3\% paraformaldehyde, and mounted on a slide in Gel/Mount (Biomedia Corp., Foster City, California, USA). Tubules were examined for fluorescein and rhodamine fluorescence in a Nikon epifluorescence microscope, photographed at high dry power $(\times 100$ real magnification), projected, and manually traced. Cells expressing PNA and B63 on the apical surface, appearing as caps, parallel to the long axis of the tubule (3-20 per CCD) were measured using calibrated calipers and averaged per CCD. Mean data from three to nine tubules were obtained for each experimental maneuver.

Confocal fluorescence microscopy of hensin-labeled CCDs. Microdissected CCDs were labeled extracellularly with anti-hensin $\mathrm{Ab}$ at 1:100 dilution in PBS/1\% BSA by exposure at $4{ }^{\circ} \mathrm{C}$ for $4-5$ hours, followed by fixation in Prefer (Anatech Ltd., Battle Creek, Michigan, USA), permeabilization, and overnight exposure to counterlabel, either rhodamine-PNA $(20 \mu \mathrm{g} / \mathrm{ml})$ or IVF12 $\mathrm{mAb}$ to band 3 (1:100), provided by M. Jennings (27). Next, the CCD was exposed to FITC-goat anti-guinea pig IgG $(1: 75)$ and, if band 3 was used, rhodamine donkey antimouse IgG (1:50). Each tubule was transferred to a slide in Gel/Mount, coverslipped, sealed, and examined using an Axiovert 100 laser-scanning confocal microscope (model LSM 410; Carl Zeiss Inc., Thornwood, New York, USA) $(25,28)$. Images were collected using a $\times 40$ objective ( $\times 100$ real magnification), and $1-\mu \mathrm{m}$ optical sections were obtained and analyzed by the Zeiss LSM-PC software. The final images were processed with Adobe Photoshop software (Adobe Systems Inc., San Jose, California, USA).

Analysis and statistics. Data are presented as means plus or minus SE. Standard paired and unpaired comparisons were performed using statistical software (NCSS 


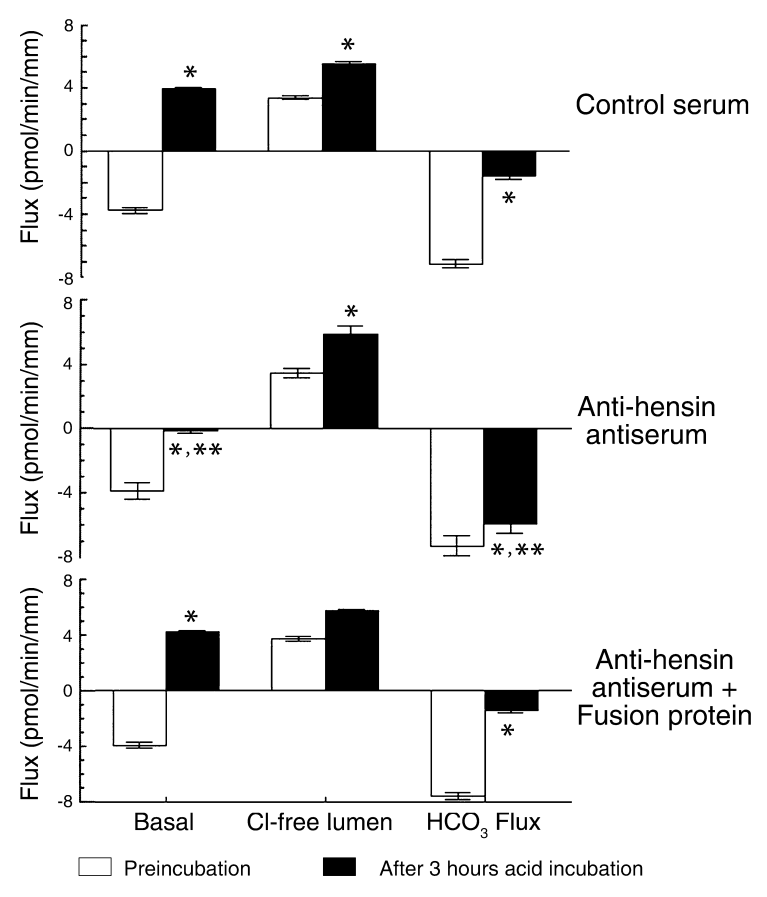

Figure 1

Acid incubation converts $\mathrm{HCO}_{3}{ }^{-}$secretion to $\mathrm{HCO}_{3}{ }^{-}$absorption, a process that is hensin-dependent. Upper panel: five CCDs (control serum, basal, white bars) secrete $\mathrm{HCO}_{3}{ }^{-}$. When $\mathrm{Cl}^{-}$was removed $(\mathrm{Cl}-$ free lumen), $\mathrm{HCO}_{3}{ }^{-}$absorption resulted; the difference is the rate of $\mathrm{Cl}^{-}$-dependent $\mathrm{HCO}_{3}{ }^{-}$secretion $\left(\mathrm{HCO}_{3}\right.$ flux). After 3-hour incubation at $\mathrm{pH} 6.8$ (black bars), net $\mathrm{HCO}_{3}{ }^{-}$absorption was observed (basal). Removal of luminal $\mathrm{Cl}^{-}$caused a small increase in $\mathrm{HCO}_{3}$ absorption ( $\mathrm{Cl}^{-}$-free lumen), and the $\mathrm{Cl}^{-}$dependent $\mathrm{HCO}_{3}{ }^{-}$secretion $\left(\mathrm{HCO}_{3}\right.$ flux) was substantially less than before acid incubation. Middle panel: five CCDs (anti-hensin antiserum) were incubated similarly, except anti-hensin Ab was included in the bath. Anti-hensin antiserum (black bars) blocked half of the acid-induced change in $\mathrm{HCO}_{3}{ }^{-}$transport (basal) but did not change the flux after removal of luminal $\mathrm{Cl}^{-}\left(\mathrm{Cl}\right.$-free lumen), so that the $\mathrm{Cl}^{-}$-dependent rate of $\mathrm{HCO}_{3}{ }^{-}$ secretion $\left(\mathrm{HCO}_{3}\right.$ flux $)$ was only slightly smaller than preincubation values. Lower panel: four CCDs (anti-hensin antiserum + fusion protein) were incubated similarly, except that hensin $A b$ had been preincubated with the fusion protein that had been used as the immunogen. After acid incubation (black bars), the pattern of net $\mathrm{HCO}_{3}^{-}$ transport (basal), $\mathrm{HCO}_{3}{ }^{-}$absorption ( $\mathrm{Cl}$-free lumen), and $\mathrm{HCO}_{3}{ }^{-}$ secretory flux was similar to that observed in the upper panel for control serum. ${ }^{*}$ Significantly different from preincubation $(P<0.05)$; ** significantly different from incubation in control serum $(P<0.05)$.

Statistical Software, Kaysville, Utah, USA; Excel, Microsoft Corp., Bellevue, Washington, USA). Significance was asserted when $P$ values were less than 0.05 .

\section{Results}

Lowering bath $\mathrm{pH}$ converts $\mathrm{HCO}_{3}{ }^{-}$secretion to $\mathrm{HCO}_{3}{ }^{-}$absorption. When CCDs from normal rabbits are perfused and bathed in vitro in solutions simulating an ultrafiltrate of rabbit plasma at $\mathrm{pH} 7.4$, they generally secrete $\mathrm{HCO}_{3}$ $(3,4)$. Similar results were observed in five CCDs that secreted $\mathrm{HCO}_{3}{ }^{-}(-3.84 \pm 0.15 \mathrm{pmol} / \mathrm{min} / \mathrm{mm})$ and had a transepithelial voltage of $-3.7 \pm 0.1 \mathrm{mV}$ (baseline, i.e., before incubation; Table 1 and Figure 1, control serum, basal, white bars). When $\mathrm{Cl}^{-}$was removed from the lumen, $\mathrm{HCO}_{3}{ }^{-}$secretion was completely reversed, and net $\mathrm{HCO}_{3}{ }^{-}$absorption of $3.34 \pm 0.11 \mathrm{pmol} / \mathrm{min} / \mathrm{mm}$ was observed (Figure 1, Cl-free lumen, white bar). The overall $\mathrm{Cl}^{-}$-dependent $\mathrm{HCO}_{3}{ }^{-}$secretion was $-7.03 \pm 0.26$ $\mathrm{pmol} / \mathrm{min} / \mathrm{mm}$ (Figure $1, \mathrm{HCO}_{3}$ Flux, white bar), similar to what has been observed previously (3).

After 3 hours of in vitro incubation in $\mathrm{pH} 6.8$ media, these same tubules changed their $\mathrm{HCO}_{3}{ }^{-}$transport rates to absorption at a rate of $3.99 \pm 0.09$ $\mathrm{pmol} / \mathrm{min} / \mathrm{mm}$, even when the CCD's were examined at $\mathrm{pH} 7.4$ (Figure 1, basal, black bar). With $\mathrm{H}^{+}$secretion, the voltage became less negative at $-3.1 \pm 0.1 \mathrm{mV}$. These results were not affected by inclusion in the bath of anti-collagen IV Ab's or nonimmune guinea pig serum (1:100 dilution) during the 3 -hour incubation at $\mathrm{pH}$ 6.8 (Table 1). Thus, all of these data were pooled. When luminal $\mathrm{Cl}^{-}$was removed after the acid incubation, there was a small increase in $\mathrm{HCO}_{3}{ }^{-}$absorptive flux to $5.45 \pm 0.20 \mathrm{pmol} / \mathrm{min} / \mathrm{mm}$ (Figure 1, Cl-free lumen, black bar) with a rate of $\mathrm{Cl}^{-}$-dependent $\mathrm{HCO}_{3}{ }^{-}$secretion that was reduced to $1.56 \pm 0.20 \mathrm{pmol} / \mathrm{min} / \mathrm{mm}$ (Figure $1, \mathrm{HCO}_{3}$ Flux, black bar). In sum, in vitro exposure to a bath of $\mathrm{pH} 6.8$ caused the CCD to reverse the polarity of $\mathrm{HCO}_{3}{ }^{-}$flux from net secretion to net absorption; the acid-induced change in net $\mathrm{HCO}_{3}{ }^{-}$flux was $7.83 \pm 0.23$ $\mathrm{pmol} / \mathrm{min} / \mathrm{mm}$. This adaptation was specific to the lowering of bath $\mathrm{pH}$ rather than to the 3-hour incubation, since we showed previously that exposure of CCDs to 3-hour incubation at $\mathrm{pH} 7.4$ (control incubation) resulted in no net change in $\mathrm{HCO}_{3}{ }^{-}$flux or transepithelial voltage (3).

Conversion of $\mathrm{HCO}_{3}{ }^{-}$secretion to $\mathrm{HCO}_{3}{ }^{-}$absorption is hensin-dependent. It had been shown in an immortalized intercalated cell line that hensin converts the low-density, i.e., $\beta$-like phenotype, to the high-density or $\alpha$-like form, and anti-hensin Ab's prevented this conversion (19). When CCDs were exposed to these Ab's in the bath during the 3-hour acid incubation, they prevented much of the adaptation (Figure 1, anti-hensin antiserum, basal, black bar). Before incubation, $\mathrm{HCO}_{3}{ }^{-}$was secreted $(-3.88 \pm 0.40 \mathrm{pmol} / \mathrm{min} / \mathrm{mm})$, while after acid incubation plus anti-hensin $\mathrm{Ab}$, the flux was not significantly different from zero. The overall change in net $\mathrm{HCO}_{3}$ - flux with acid incubation was reduced by $52 \%$ to $3.76 \pm 0.37 \mathrm{pmol} / \mathrm{min} / \mathrm{mm}$, significantly less than that observed after low $\mathrm{pH}$ incubation in the presence of irrelevant Ab's. The acid-induced decrease in electronegativity of transepithelial voltage was significantly attenuated to only $0.2 \mathrm{mV}$. These data indicate that the anti-hensin Ab's prevented the adaptation. Preincubation of the Ab's with the immunizing fusion protein completely prevented the effect of the Ab's (Figure 1, lower panel).

To examine which unidirectional flux of $\mathrm{HCO}_{3}{ }^{-}$was affected by hensin, we removed luminal $\mathrm{Cl}^{-}$. The change in flux due to $\mathrm{Cl}^{-}$removal (i.e., the $\mathrm{HCO}_{3}{ }^{-}$secretory flux) was reduced in response to acid incubation. When the tubules were incubated in irrelevant Ab's, the $\mathrm{HCO}_{3}$ 


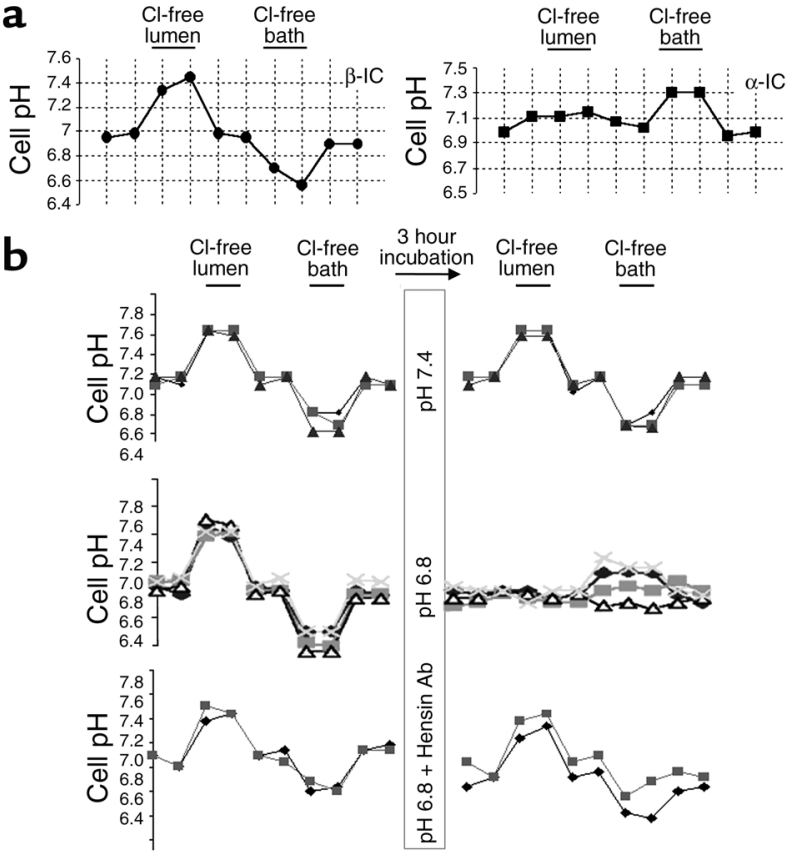

secretory flux was $-7.20 \pm 0.59 \mathrm{pmol} / \mathrm{min} / \mathrm{mm}$ before acid incubation and $-1.56 \pm 0.20 \mathrm{pmol} / \mathrm{min} / \mathrm{mm}$ after incubation (Figure 1, control serum, $\mathrm{HCO}_{3}$ flux). In contrast, the tubules that were exposed to anti-hensin antiserum plus low $\mathrm{pH}$ showed only a small change in their $\mathrm{HCO}_{3}{ }^{-}$secretory flux $(-7.20 \pm 0.59 \mathrm{pmol} / \mathrm{min} / \mathrm{mm}$ before acid incubation and $-5.90 \pm 0.54 \mathrm{pmol} / \mathrm{min} / \mathrm{mm}$ after; see Figure 1, anti-hensin antiserum, $\mathrm{HCO}_{3}$ flux, black bar). After acid incubation in the presence of hensin $\mathrm{Ab}$ 's, the $\mathrm{HCO}_{3}{ }^{-}$secretory flux was significantly larger than if exposed to irrelevant Ab's (see Figure 1, control serum, $\mathrm{HCO}_{3}$ flux, black bar). These studies suggest that the adaptive decrease in $\mathrm{HCO}_{3}{ }^{-}$secretion to in vitro acid treatment is mediated by hensin. The flux remaining after removal of luminal $\mathrm{Cl}^{-}$represents $\mathrm{HCO}_{3}$ absorption, i.e., $\mathrm{H}^{+}$secretion. This flux was stimulated by in vitro acid incubation from 3.3 to 5.5 $\mathrm{pmol} / \mathrm{min} / \mathrm{mm}$. Interestingly, hensin Ab's did not block this acid-induced stimulation.

Identification of individual intercalated cells. We had used the $\mathrm{pH}$ sensitive dye, BCECF, to identify subtypes of intercalated cells, finding that removal of luminal $\mathrm{Cl}^{-}$ led to alkalinization of $\beta$-type intercalated cells $(4,5,10,29)$ since $\mathrm{HCO}_{3}{ }^{-}$secretion was inhibited, whereas $\alpha$-type intercalated cells did not respond because they lacked apical anion exchangers or channels (30). Removal of bath $\mathrm{Cl}^{-}$resulted in alkalinization of $\alpha$-intercalated cells, because basolateral base exit via the $\mathrm{Cl}^{-} / \mathrm{HCO}_{3}{ }^{-}$exchanger is inhibited $(4,6,15)$. Basolat-

\section{Figure 2}

Identification of individual intercalated cells and their response to 3-hour incubation. (a) Perfusion of CCDs with BCECF-AM results in selective concentration of fluorescence in intercalated cells. Left tracing shows a $\beta$-intercalated cell, which alkalinizes with removal of luminal $\mathrm{Cl}^{-}$and acidifies upon removal of bath $\mathrm{Cl}^{-}$. Right tracing shows an $\alpha$-intercalated cell, which is unresponsive to the removal of luminal $\mathrm{Cl}^{-}$, but alkalinizes upon the removal of bath $\mathrm{Cl}^{-}$. (b) Representative tracings of $\mathrm{pH}$ changes in $\beta$-intercalated cells presented to illustrate the variety of responses to $\mathrm{Cl}^{-}$removal under different incubation conditions. Top panel: Incubation at $\mathrm{pH} 7.4$ has no effect on the response of $\beta$-intercalated cells to removal of $\mathrm{Cl}^{-}$. Middle panel: Incubation at $\mathrm{pH} 6.8$ causes a loss of apical $\mathrm{Cl}^{-} / \mathrm{HCO}_{3}{ }^{-}$exchange activity and prevents acidification with the removal of bath $\mathrm{Cl}^{-}$. Moreover, two of four $\beta$-intercalated cells (diamonds and x's) now alkalinize after basolateral $\mathrm{Cl}^{-}$removal. The responses of all cells are depicted in Figure 4. Lower panel: Anti-hensin $\mathrm{Ab}$ added with the $\mathrm{pH}$ 6.8 incubation prevented the loss of apical $\mathrm{Cl}^{-} / \mathrm{HCO}_{3}{ }^{-}$exchange and permits acidification with bath $\mathrm{Cl}^{-}$removal.

eral $\mathrm{Cl}^{-}$removal, however, acidifies $\beta$-intercalated cells, because $\mathrm{HCO}_{3}{ }^{-}$exit from the cell into the lumen via the apical $\mathrm{Cl}^{-} / \mathrm{HCO}_{3}^{-}$exchanger is accelerated in the absence of bath (and therefore cellular) $\mathrm{Cl}^{-}(5,10)$. We used this approach to identify individual intercalated cells before and after acid incubation. The upper panel of Figure $2 \mathrm{a}$ shows the response of typical intercalated cells; the $\beta$ form (upper tracing) reversibly alkalinizes $0.4 \mathrm{pH}$ units upon removal of luminal $\mathrm{Cl}^{-}$and acidifies $0.4 \mathrm{pH}$ units upon removal of bath $\mathrm{Cl}^{-}$. The $\alpha$-intercalated cell (Figure 2a, lower tracing) does not change cell $\mathrm{pH}$ with luminal $\mathrm{Cl}^{-}$removal and reversibly alkalinizes 0.3 units after removal of bath $\mathrm{Cl}^{-}$. In the mid-CCD, the vast majority of intercalated cells were $\beta$ type; a few resembled $\alpha$-intercalated cells, similar to what has been found previously $(6,10)$. These two functional phenotypes were the only ones observed in BCECF-positive cells in the mid-CCD.

To secrete $\mathrm{HCO}_{3}$ in a transepithelial manner, a $\beta$ cell has to have a $\mathrm{Cl}^{-} / \mathrm{HCO}_{3}{ }^{-}$exchanger on the apical membrane and $\mathrm{H}^{+}$-ATPase on the basolateral membrane.

\section{Table 2}

$\beta$-Intercalated cell $\mathrm{pH}$ values

\begin{tabular}{lccccr} 
& \multicolumn{3}{c}{ Before incubation } & \multicolumn{2}{c}{ After incubation } \\
Incubation & $n$ & First pH & Last $\mathrm{pH}$ & First $\mathrm{pH}$ & Last $\mathrm{pH}$ \\
$\mathrm{pH} \mathrm{7.4}$ & 15 & $7.13 \pm 0.03$ & $7.14 \pm 0.05$ & $6.94 \pm 0.06^{\mathrm{A}}$ & $6.95 \pm 0.06$ \\
$\mathrm{pH} \mathrm{6.8}$ & 75 & $7.15 \pm 0.02$ & $7.03 \pm 0.03^{\mathrm{A}}$ & $7.07 \pm 0.01$ & $7.12 \pm 0.03^{\mathrm{A}}$ \\
$\mathrm{pH} \mathrm{6.8} \mathrm{+} \mathrm{Hens} \mathrm{Ab}$ & 21 & $7.17 \pm 0.03$ & $7.12 \pm 0.03$ & $6.92 \pm 0.03^{\mathrm{A}}$ & $6.95 \pm 0.04$ \\
$\mathrm{pH} \mathrm{6.8} \mathrm{+} \mathrm{Colch}$ & 20 & $7.06 \pm 0.03$ & $7.08 \pm 0.04$ & $7.10 \pm 0.04$ & $7.10 \pm 0.03$ \\
$\mathrm{pH} \mathrm{6.8} \mathrm{+} \mathrm{Cyt} \mathrm{D}$ & 9 & $7.15 \pm 0.03$ & $7.06 \pm 0.04$ & $7.02 \pm 0.03$ & $7.06 \pm 0.03$ \\
$\mathrm{pH} \mathrm{6.8} \mathrm{+} \mathrm{Aniso}$ & 16 & $7.06 \pm 0.02$ & $7.02 \pm 0.02$ & $7.04 \pm 0.02$ & $7.02 \pm 0.02$ \\
$\mathrm{pH} \mathrm{6.8} \mathrm{+} \mathrm{BAPTA}$ & 7 & $7.09 \pm 0.02$ & $7.02 \pm 0.01^{\mathrm{A}}$ & $7.05 \pm 0.06$ & $6.98 \pm 0.09$
\end{tabular}

$\beta$-Intercalated cell $\mathrm{pH}$ values obtained in the presence of Burg's solution $(\mathrm{pH} 7.4)$ in both luminal and bathing solutions before and after a 3-hour incubation. ${ }^{A}$ Significantly different from preceding value. $n$, number of cells; Hens $\mathrm{Ab}$, hensin Ab (1:100); Colch, colchicine $(10 \mu \mathrm{M})$; Cyt D, cytochalasin D $(0.2 \mu \mathrm{M})$; Aniso, anisomycin $(10 \mu \mathrm{M})$. 


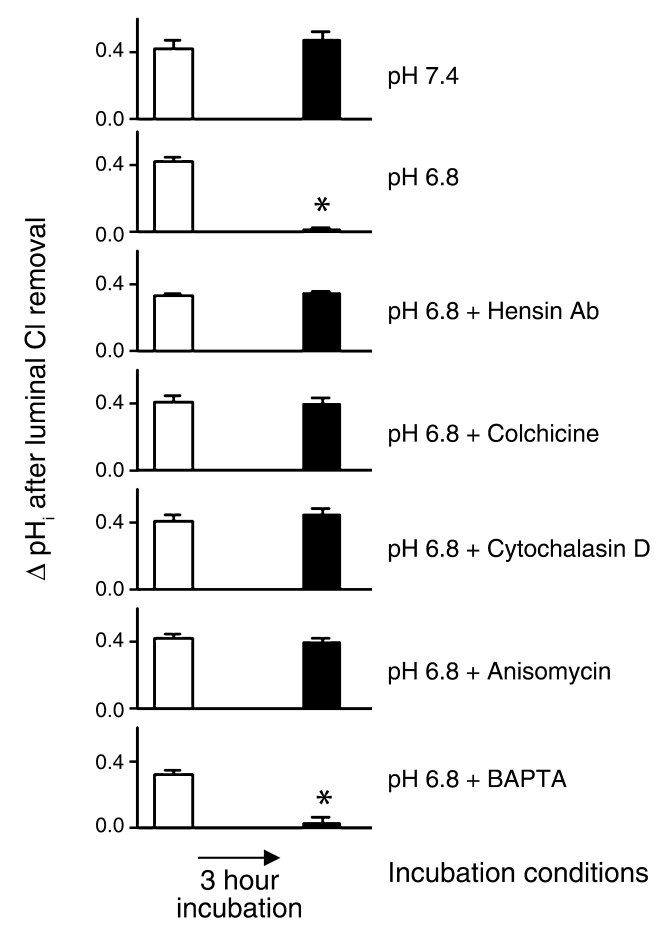

Figure 3

Loss of apical $\mathrm{Cl}^{-} / \mathrm{HCO}_{3}{ }^{-}$exchange activity in response to acid incubation is an adaptation that is prevented not only by hensin $A b$, but also by cytoskeletal and protein synthesis inhibitors; this adaptation does not depend on changes in cell calcium. Mean $( \pm S E)$ reversible change in cell $\mathrm{pH}$ upon removal of luminal $\mathrm{Cl}^{-}$in $\beta$-intercalated cells before incubation (white bars) and after incubation (black bars). * Significantly different from preincubation value.

In this study, those intercalated cells that had apical $\mathrm{Cl}^{-} / \mathrm{HCO}_{3}{ }^{-}$exchange were classified as $\beta$ cells. At this time there is no procedure to measure $\mathrm{H}^{+}$pumping in individual cells repeatedly without drastic changes in cell $\mathrm{pH}$, an action that itself might change the distribution of transporters. Others $(9,14)$ using immunocytochemistry found that the $\mathrm{H}^{+}$-ATPase of many $\beta$ cells is located in intracellular vesicles but not on the basolateral membrane. It is therefore likely that some $\beta$ cells with apical $\mathrm{Cl}^{-} / \mathrm{HCO}_{3}{ }^{-}$exchange actually secrete $\mathrm{HCO}_{3}{ }^{-}$while others do not. Our use of apical or basolateral $\mathrm{Cl}^{-} / \mathrm{HCO}_{3}{ }^{-}$exchange as a marker for $\beta$ or $\alpha$ cells overestimates the number of cells that participate in transepithelial transport.

An acid bath in vitro induces loss of apical $\mathrm{Cl}^{-} / \mathrm{HCO}_{3}-$ exchange by a hensin-mediated mechanism. We first showed that the phenotype of $\beta$-intercalated cells did not change after a 3-hour incubation at $\mathrm{pH} 7.4$ (Figure 2b, upper tracing). In 15 cells from five CCDs, the mean reversible increase in cell $\mathrm{pH}$ upon removal of luminal $\mathrm{Cl}^{-}$was $0.43 \pm 0.04$ units before and $0.47 \pm 0.05$ units after incubation at $\mathrm{pH} 7.4$ (Figure 3, pH 7.4). While there was a small decrease in the steady state cell $\mathrm{pH}$ after this incubation, this was not observed after most other maneuvers (Table 2). These studies confirm that a 3-hour incubation does not alter this fundamental property of $\beta$-intercalated cell function (3). In contrast, incubation for 3 hours at $\mathrm{pH} 6.8$ caused a complete loss of sensitivity to luminal $\mathrm{Cl}^{-}$removal (Figure $2 \mathrm{~b}$, middle tracing; Figure 3, pH 6.8). In 75 cells from 21 CCDs, the mean reversible increase in cell $\mathrm{pH}$ upon the removal of luminal $\mathrm{Cl}^{-}$was $0.42 \pm 0.01$ units before and $0.02 \pm 0.01$ units after incubation at $\mathrm{pH} 6.8(P<0.001)$. Note that the same cells were examined before and after $\mathrm{Cl}^{-}$ removal and acid incubation, thereby establishing the fact that an individual identified intercalated cell responded to a change in ambient $\mathrm{pH}$ with loss of luminal $\mathrm{Cl}^{-} / \mathrm{HCO}_{3}{ }^{-}$exchangers. The consequence, seen in Figure 1, was a downregulation of $\mathrm{HCO}_{3}^{-}$secretion and $\mathrm{Cl}^{-}$-dependent change in $\mathrm{HCO}_{3}{ }^{-}$flux.

When hensin $\mathrm{Ab}$ was added to the bath during the $\mathrm{pH}$ 6.8 incubation, this adaptive loss of $\mathrm{Cl}^{-} / \mathrm{HCO}_{3}{ }^{-}$exchange was prevented (Figure 2b, lowest tracing). Indeed, in 21 cells from seven CCDs, the mean reversible increase in cell $\mathrm{pH}$ upon the removal of luminal $\mathrm{Cl}^{-}$was $0.33 \pm 0.02$ units before and $0.35 \pm 0.02$ units after incubation at $\mathrm{pH}$ 6.8 (Figure 3, pH $6.8+$ hensin Ab). Although hensin Ab's completely prevented the loss of apical $\mathrm{Cl}^{-} / \mathrm{HCO}_{3}{ }^{-}$ exchange, they only partially restored the $\mathrm{HCO}_{3}{ }^{-}$secretory flux (Figure 1). We conclude that some cells that had apical $\mathrm{Cl}^{-} / \mathrm{HCO}_{3}{ }^{-}$exchange must not have basolateral $\mathrm{H}^{+}$-ATPase activity and therefore were not participating in the transepithelial flux activity.

Metabolic acidosis in vitro induces a reversal in polarity of $\mathrm{Cl}-/ \mathrm{HCO}_{3}{ }^{-}$exchange activity. To examine whether the adapted $\beta$-intercalated cells changed their phenotype to that of the $\alpha$ type, we measured their response to basolateral $\mathrm{Cl}^{-}$removal, a maneuver that results in acidification of $\beta$-cell pH (see Figure 2). Control studies demonstrated that a 3-hour incubation at $\mathrm{pH} 7.4$ had no effect on this $\mathrm{Cl}^{-}$-dependent acidification of cell $\mathrm{pH}$ $(0.34 \pm 0.04$ units before and $0.34 \pm 0.07$ units after incubation; Figure $2 \mathrm{~b}$, top tracing). When seven cells from five CCDs were studied and the responses presented in histogram form (Figure 4, pH 7.4) the distribution before incubation (white bars) did not differ from that after incubation (black bars).

However, the response of cell $\mathrm{pH}$ to bath $\mathrm{Cl}^{-}$removal after incubation at $\mathrm{pH} 6.8$ (Figure 2b, middle panel) was quite different: some cells showed no change in cell $\mathrm{pH}$, while others showed a substantial alkalinization. Overall, in 51 cells from 16 CCDs, the mean change in cell $\mathrm{pH}$ with bath $\mathrm{Cl}^{-}$removal before incubation was $-0.29 \pm 0.02$ units compared with $0.01 \pm 0.02$ units after incubation $(P<0.001)$. The histogram of all responses (Figure 4, pH 6.8) shows that $39 \%$ of previously identified $\beta$-intercalated cells had now alkalinized in response to bath $\mathrm{Cl}^{-}$removal (black bars); tracings of four adapting $\beta$-intercalated cells, two of which clearly show alkalinization with removal of bath $\mathrm{Cl}^{-}$after acid incubation, are depicted in Figure 2b (middle panel). These data indicate that a substantial proportion of individually identified $\beta$-intercalated cells have lost apical and gained basolateral $\mathrm{Cl}^{-} / \mathrm{HCO}_{3}{ }^{-}$exchange activity, two of the key properties of $\alpha$-intercalated cells (see 
Figure 2a), confirming unequivocally our original idea of the plasticity of epithelial polarity.

Acid incubation also stimulates basolateral $\mathrm{Cl}^{-} / \mathrm{HCO}_{3}{ }^{-}$ exchange activity in $\alpha$-intercalated cells. While the vast majority of intercalated cells in the mid-CCD responded as $\beta$-intercalated cells, several $\alpha$-intercalated cells ( $4 \%$ of total intercalated cells) were also identified. In six $\alpha$ cells examined in four CCDs, the mean alkalinization resulting from removing bath $\mathrm{Cl}^{-}$was $0.34 \pm 0.02 \mathrm{pH}$ units before acid incubation and $0.47 \pm 0.03 \mathrm{pH}$ units after acid incubation, a 36\% increase $(P<0.05)$. These data are consistent with increased expression of apical $\mathrm{H}^{+}$-ATPase and basolateral band 3 in $\alpha$ cells after chronic metabolic acidosis in vivo $(7,31)$.

Hensin $A b$ prevents the adaptive gain of basolateral $\mathrm{Cl}^{-} / \mathrm{HCO}_{3}{ }^{-}$exchange activity. When $\mathrm{Ab}$ to hensin was added to the bath during the 3 -hour incubation at $\mathrm{pH}$ 6.8 , there was no apparent adaptation at the basolateral side of the $\beta$-intercalated cells. In 16 cells from six CCDs, the mean reversible acidification in response to removal of bath $\mathrm{Cl}^{-}$was $0.28 \pm 0.02$ units before and $0.22 \pm 0.02$ units after the 3 -hour incubation at $\mathrm{pH} 6.8$ plus hensin $\mathrm{Ab}$ (Figure 2b, lower tracing). The histogram of all responses (Figure 4, $\mathrm{pH} 6.8+$ hensin $\mathrm{Ab}$ ) confirmed that there were no significant changes in the distribution of responses to bath $\mathrm{Cl}^{-}$removal.

The apical surface of $\beta$-intercalated cells diminishes in response to acidosis in vitro. Assuming that a reduction of apical $\mathrm{Cl}^{-} / \mathrm{HCO}_{3}{ }^{-}$exchange activity would be accomplished by endocytosis of part of the apical membrane, we examined changes in two different apical markers of $\beta$-intercalated cells, PNA $(5,9,10)$ and binding of the $\mathrm{mAb} \mathrm{B} 63$ (26). In five CCDs, a 3-hour control incubation at $\mathrm{pH} 7.4$ resulted in a mean apical PNA cap length of $8.7 \pm 0.3 \mu \mathrm{m}$ and a mean B63 cap length of $9.2 \pm 0.3$ $\mu \mathrm{m}$ (Figure 5, $\mathrm{pH}$ 7.4). In six CCDs, incubation for 3 hours at $\mathrm{pH} 6.8$ resulted in significant reductions in cap length to $7.3 \pm 0.2 \mu \mathrm{m}$ for PNA $(P<0.05)$ and $7.3 \pm 0.3$ $\mu \mathrm{m}$ for B63 $(P<0.05)$ (Figure 5, $\mathrm{pH} 6.8)$. Previous studies suggested that this reduction in cap length is a consequence of endocytosis of these apical markers. Studies in vivo $(4,5)$ and in the intercalated cell line in vitro $(18,24)$ had demonstrated that induction of apical endocytosis is one of the first phenomena to occur during conversion of $\beta$ - to $\alpha$-intercalated cell phenotypes. These findings suggest that endocytic removal of apical $\mathrm{Cl}^{-} / \mathrm{HCO}_{3}{ }^{-}$exchangers results in reduction of apical membrane area of $\beta$-intercalated cells.

Plasticity of intercalated cells is associated with deposition of hensin in the ECM. Hensin is a $250-\mathrm{kDa}$ protein that is expressed in all cells of ureteric bud lineage, i.e., both principal and intercalated cells (19). In most of these cells it is present in intracellular vesicles. Previous studies in the intercalated cell line demonstrated that for hensin to activate its receptor, it must be deposited in the extracellular matrix as an insoluble fiber composed of a homomultimer whose structure is stabilized by binding to galectin-3 (28). Only this form of hensin is active, and monomeric hensin, the form pres- ent in intracellular vesicles, does not induce the reversal of polarity. That Ab's to hensin inhibited the response of isolated perfused CCDs also suggest that it is the ECM form of hensin that is responsible for conversion of $\beta$ - to $\alpha$-intercalated cells demonstrated above, since the Ab's are large molecules and do not have access to any intracellular structures. To demonstrate whether hensin was present in the ECM of the CCDs, it was necessary to develop methods that would assay for its presence only in the ECM and not intracellularly, since all cells of these segments express
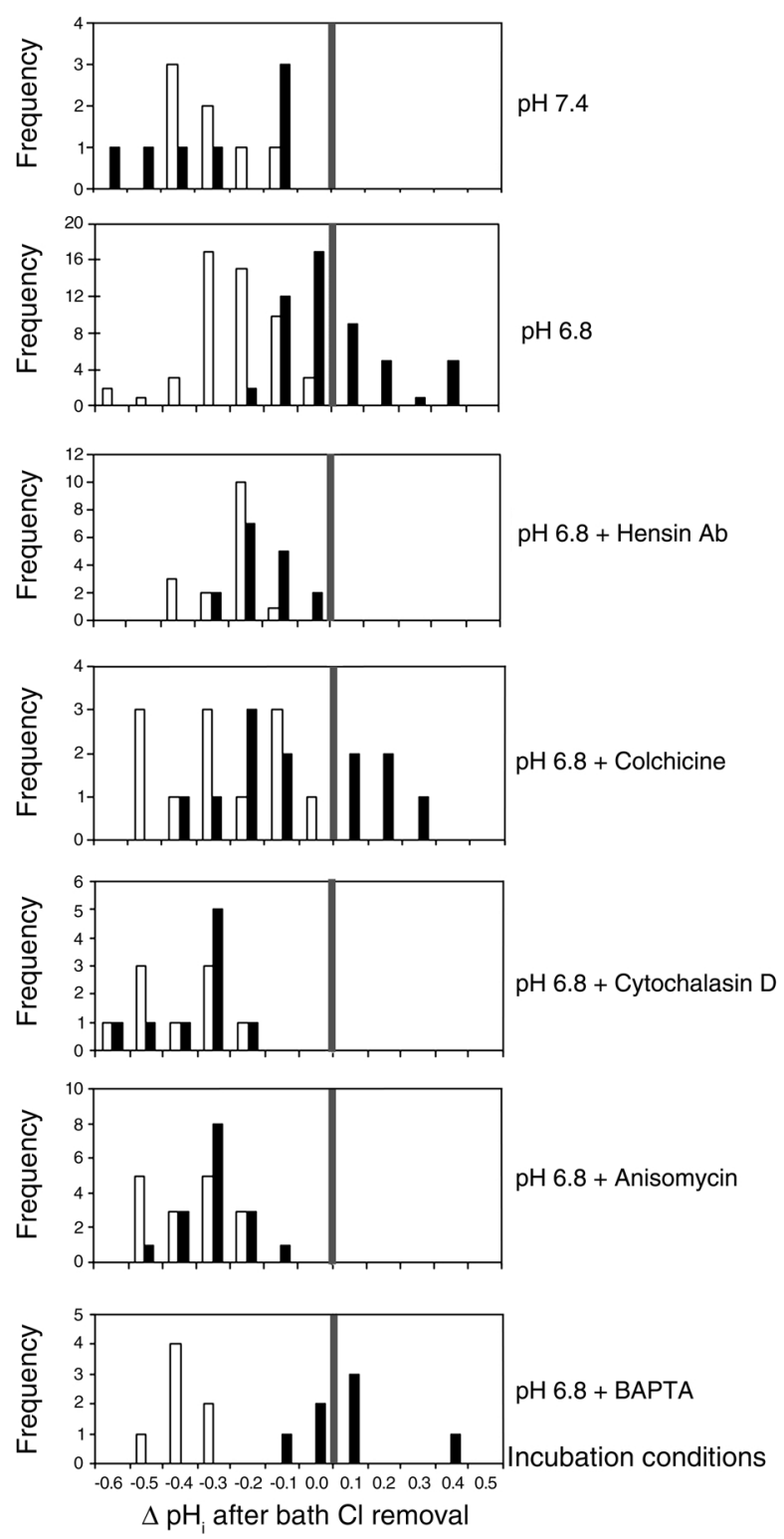

\section{Figure 4}

Acid incubation induces a reversal of polarity of $\mathrm{Cl}^{-} / \mathrm{HCO}_{3}{ }^{-}$exchangers, a process that is hensin-dependent and mediated by intact microfilaments and protein synthesis; this adaptation is independent of changes in cell calcium. Histogram of changes in cell $\mathrm{pH}\left(\mathrm{pH}_{\mathrm{i}}\right)$ induced by removal of bath $\mathrm{Cl}^{-}$before 3-hour incubation (white bars) and after incubation (black bars). The shaded vertical bar in each graph is a marker for no change in $\mathrm{pH}_{i}$ with removal of bath $\mathrm{Cl}^{-}$. 


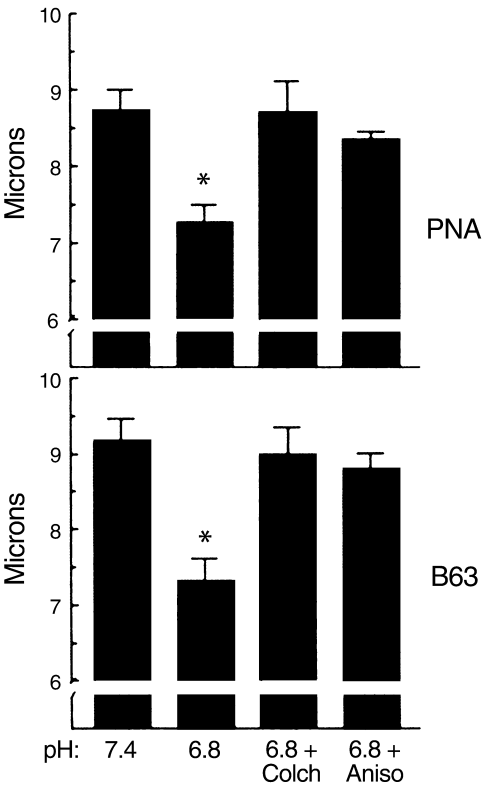

Figure 5

Apical surface (cap length) of $\beta$-intercalated cells is diminished by incubation at low $\mathrm{pH}$, in a process that depends on microtubules and protein synthesis. Apical surface of $\beta$-intercalated cells was measured from photographs of perfused CCDs labeled with PNA (upper graph) and B63 (lower graph), both specific markers of such cells. ${ }^{*}$ Significantly different from control incubation $(\mathrm{pH} 7.4) .6 .8$, incubation at $\mathrm{pH} 6.8$ for 3 hours; colch, colchicine $(10 \mu \mathrm{M})$; aniso, anisomycin $(10 \mu \mathrm{M})$.

hensin. To prevent cellular permeabilization required exposure of microdissected CCDs to hensin Ab's at $4^{\circ} \mathrm{C}$ for $4-5$ hours, followed by washing, fixation, and then detergent permeabilization, in order to assay for the presence of PNA (the marker of $\beta$ cells) and band 3 (the marker for $\alpha$ cells). Confocal microscopy showed that $\beta$-intercalated cells expressed thick, wellformed caps on the apical membrane that contained the PNA-binding protein (Figure 6, cell 2). These cells had no basal or lateral hensin in the ECM in the unpermeabilized state. In CCDs taken from 3-day acid-treated rabbits, the PNA caps of $\beta$-cells had lost the thick and well-defined structure, converting to a variety of patterns varying from thin and short images to a few punctate structures, which might represent PNA that was internalized by apical endocytosis (Figure 6, compare cells 1 and 3 ). The hensin staining was localized to the basal and lateral surface of only a few of the cells in the acid-treated CCD (cell 1 or 3 , for instance), likely to be the adapting $\beta$-intercalated cells. However, most of the cells in both control and acidtreated CCD (presumably principal cells) had no such staining (Figure 6). Alpha cells in CCDs from acidotic rabbits were abundant, as previously noted $(4,5)$, and also had extracellular hensin; this was best seen in the outer medullary collecting duct (OMCD), a segment with abundant $\alpha$ cells (Figure 7).

Role of cell calcium in the adaptive change in polarity of $\mathrm{Cl}^{-} / \mathrm{HCO}_{3}{ }^{-}$exchange. We had shown previously that acute intracellular acidification by $\mathrm{CO}_{2}$ of $\alpha$-intercalated cells leads to an increase in cell calcium with consequent increase in $\mathrm{H}^{+}$transport, an effect that was prevented by BAPTA-AM, a permeable intracellular calcium chelator (32). To examine whether the more long-term adaptation to an acid environment also involves elevation of cell calcium, we incubated CCDs for 3 hours at $\mathrm{pH} 6.8$ in the presence of BAPTA to blunt any increase in cell calcium. This treatment failed to prevent the adaptive loss of apical $\mathrm{Cl}^{-} / \mathrm{HCO}_{3}{ }^{-}$exchange activity (Figure 3) and the gain of basolateral $\mathrm{Cl}^{-} / \mathrm{HCO}_{3}{ }^{-}$exchange activity in response to acid incubation. The histogram of all basolateral responses (Figure 4, pH 6.8 + BAPTA) indicated that $57 \%$ of previously identified $\beta$-intercalated cells had now alkalinized in response to the removal of bath $\mathrm{Cl}^{-}$(black bars).

Plasticity in epithelial polarity requires protein synthesis. The conversion of $\beta$ - to $\alpha$-intercalated cells requires a complex remodeling of the cell as well as induction of apical endocytosis. To examine whether new proteins are needed for this induction we incubated CCDs for 3 hours at $\mathrm{pH} 6.8$ in the presence of anisomycin, a reversible inhibitor of protein synthesis. This reagent prevented the adaptive decrease in apical Cl-${ }^{-} / \mathrm{HCO}_{3}-$ exchange activity (Figure 3) and any significant changes in the distribution of responses to the removal of bath $\mathrm{Cl}^{-}$(Figure 4, pH $6.8+$ Anisomycin). Finally, the remodeling of the apical membrane as assayed by the cap length method was also prevented by anisomycin in three CCDs. The mean PNA and B63 cap lengths were not significantly affected by acid incubation plus anisomycin (Figure 5). These results demonstrate that all the examined characteristics of plasticity appear to require new protein synthesis.

Plasticity in epithelial polarity requires an intact cytoskeletal network. Induction of apical endocytosis and the transport of an anion exchanger to the basolateral membrane clearly require an intact cytoskeleton. In addition, it had been demonstrated that $\beta$-intercalated cells are shorter and flatter than the $\alpha$-phenotype (25), and effecting changes in cell shape depends on an intact cytoskeleton. We found that cytochalasin and colchicine, disrupters of actin and microtubules, respectively, both prevented the adaptive loss in apical $\mathrm{Cl}^{-} / \mathrm{HCO}_{3}{ }^{-}$exchange activity in response to acid incubation (Figure 3). Colchicine, however, did not inhibit some intercalated cells from acquiring basolateral $\mathrm{Cl}^{-} / \mathrm{HCO}_{3}{ }^{-}$exchange, as shown in the histogram in Figure 4. A third of previously identified $\beta$-intercalated cells had now alkalinized in response to the removal of bath $\mathrm{Cl}^{-}$(black bars). On the other hand, cytochalasin prevented the acquisition of basolateral $\mathrm{Cl}^{-} / \mathrm{HCO}_{3}{ }^{-}$exchange activity in response to acid incubation (Figure 4).

Colchicine prevented the adaptive decrease in apical cap length, much as it prevented the decrease in apical activity. In three CCDs, incubation for 3 hours at pH 6.8 plus colchicine resulted in a mean PNA cap length of $8.7 \pm 0.4 \mu \mathrm{m}$ and a mean B63 cap length of $9.0 \pm 0.3 \mu \mathrm{m}$, not significantly different from a control incubation (Figure 5, 6.8 + Colch). Thus, this 
Control

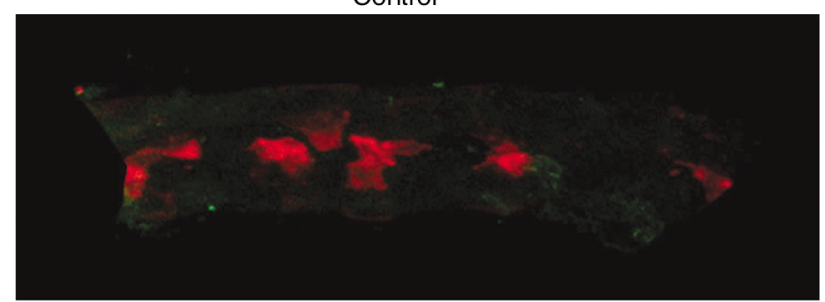

3 days acid loading
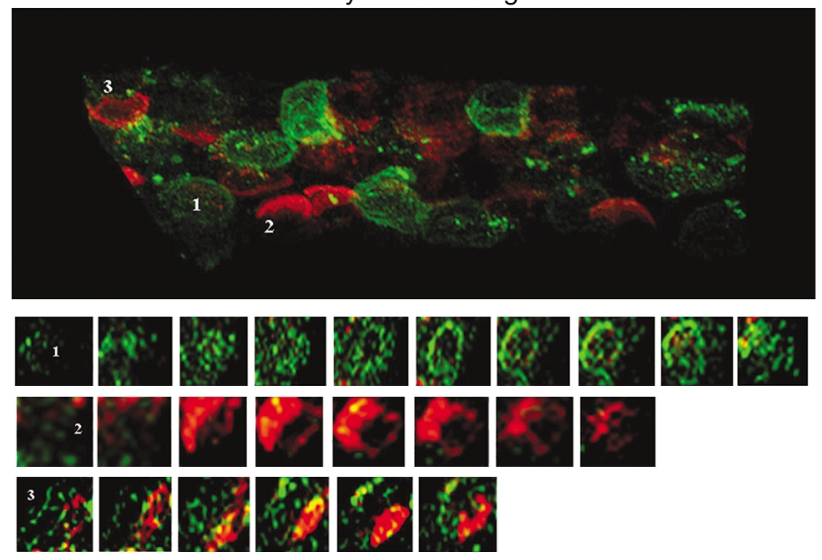

Figure 6

Confocal immunofluorescent imaging of isolated CCDs stained for extracellular hensin (green) and peanut agglutinin (PNA, red); real magnification was $\times 100$. Upper two panels show a CCD from control and 3-day acid-treated rabbit kidneys; there are three identified intercalated cells from the latter CCD. Lower three panels show successive $1-\mu \mathrm{m}$ optical cuts for each of these cells.

endocytic process of apical membrane removal from the $\beta$-intercalated cell after acid incubation requires intact microtubules. This process is consistent with a remodeling of $\beta$-intercalated cells that are adapting to metabolic acidosis in vitro.

\section{Discussion}

Several years ago (4), we showed that the cortical collecting tubule has two distinct functional subtypes of intercalated cells: the $\mathrm{H}^{+}$-secreting or $\alpha$ type has an apical $\mathrm{H}^{+}$-ATPase and basolateral $\mathrm{Cl}^{-} / \mathrm{HCO}_{3}{ }^{-}$exchanger and exhibits vigorous apical endocytosis. The $\mathrm{HCO}_{3}{ }^{-}-$ secreting or $\beta$ type has an apical $\mathrm{Cl}^{-} / \mathrm{HCO}_{3}{ }^{-}$exchanger and a basolateral $\mathrm{H}^{+}$-ATPase and binds peanut lectin on the apical membrane but has no apical endocytosis. In vivo acid loading resulted in a decrease in the number of $\beta$-intercalated cells and an increase in the number of $\alpha$-cells in CCDs from these animals, and the perfused CCDs absorbed $\mathrm{HCO}_{3}{ }^{-}$after acid loading, compared with secreting $\mathrm{HCO}_{3}{ }^{-}$in normal animals. From these data, we proposed that acid loading in vivo caused a reversal of functional epithelial polarity. Although we found no evidence for increased mitotic activity, we were unable, then, to monitor the same cell during this adaptation, hence the question of whether the same cell converted its polarity remained unanswered. Although we initially thought that the adaptation required a long period of acid loading, recent studies showed that incubating CCDs for only 3 hours at $\mathrm{pH} 6.8$ in vitro caused this reversal of polarity of $\mathrm{HCO}_{3}{ }^{-}$flux from net secretion to net absorption (3, 5, 16). This procedure, as well as improvements in optical methods, now allowed us to study individual cells before and after in vitro acid incubation. We found that $\mathrm{HCO}_{3}{ }^{-}$-secreting $\beta$-intercalated cells removed $\mathrm{Cl}^{-} / \mathrm{HCO}_{3}{ }^{-}$exchangers from the apical membrane and began to insert $\mathrm{Cl}^{-} / \mathrm{HCO}_{3}{ }^{-}$exchangers on the basolateral membrane. This complex process required protein synthesis, an intact cytoskeletal network of actin and tubulin, as well as degradation and internalization of the apically located peanut lectin-binding protein. Hence, we believe that we have provided unequivocal evidence that acid treatment can convert one intercalated cell type to another.

Role of hensin in the acid-induced plasticity of polarity. To examine the molecular basis of this transformation we generated a conditionally immortalized clonal intercalated cell line whose phenotype resembled those of the $\beta$-intercalated cells in situ. When these cells were seeded at low density and allowed to form a confluent epithelium, they showed apical $\mathrm{Cl}^{-} / \mathrm{HCO}_{3}{ }^{-}$exchange and basolateral $\mathrm{H}^{+}$-ATPase, a phenotype consistent with $\beta$ cells. Seeded at superconfluent density, they changed their phenotype to that of $\alpha$ cells, expressing all of their
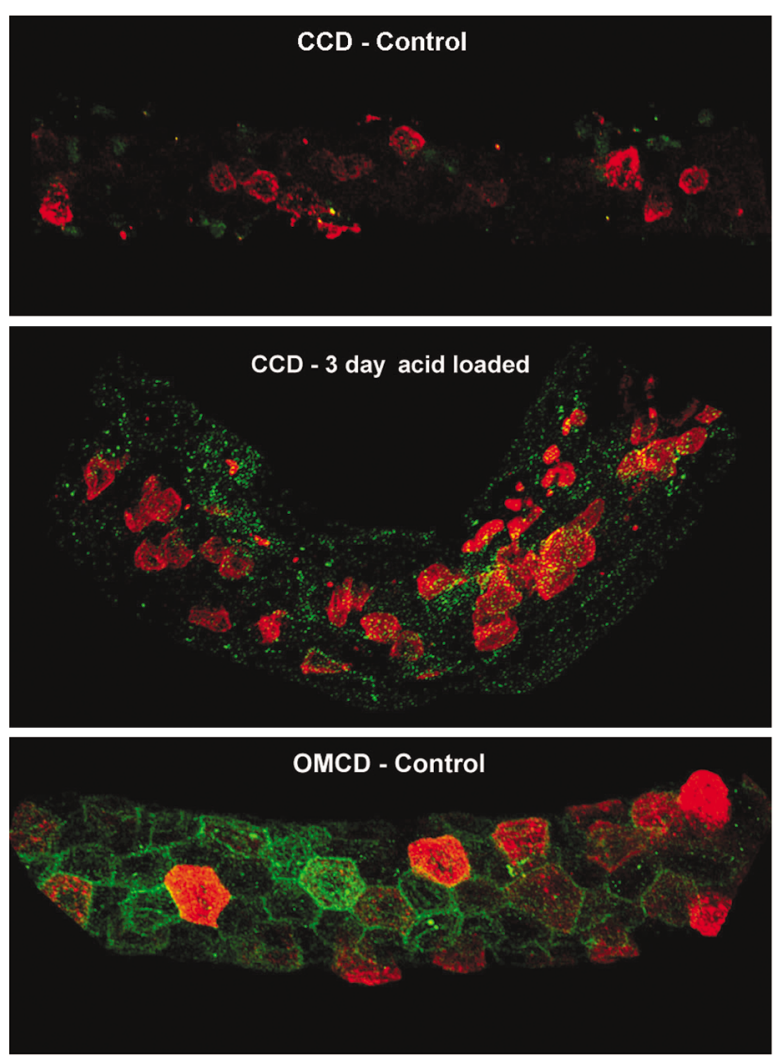

Figure 7

Confocal immunofluorescent imaging of isolated collecting ducts stained for extracellular hensin (green) and band 3 (AE1, red); real magnification was $\times 100$. Top panel: control CCD, middle panel: 3-day acid-treated CCD; bottom panel: control OMCD. 
characteristics, including vigorous apical endocytosis (24). While the relation of seeding density to acid treatment is obscure, we felt that the end result was sufficiently similar to that in situ that the two pathways were likely to intersect at some point. We identified a protein that mediates this change of phenotype and named it hensin (for change in body in Japanese). Low-density cells, resembling $\beta$ cells, secreted monomeric hensin to the basolateral medium, whereas the $\alpha$-like high-density cells secreted multimers of hensin, which become deposited in the ECM (18). When purified, this ECM form of hensin was able to induce conversion of polarity of the low-density cells. In high-density cells, monomeric hensin is first converted to dimers or tetramers by a folding enzyme located in the ECM, then it is "bundled" into fibers by galectin-3 (28). That Winyard et al. (33) had demonstrated that galectin-3 was only expressed in the $\alpha$-intercalated cells suggested that our hope of intersection of the density-mediated and acid-induced pathways was reasonable.

Hensin is a protein that is composed of three types of domains, eight SRCR domains, two CUB domains, and one ZP domain (34). Ab's against SRCR domains 6 and 7 prevented the development of the high-density phenotype and inhibited apical endocytosis $50-70 \%$ (18, 19). Similarly, these Ab's significantly reduced the adaptive inhibition of $\mathrm{HCO}_{3}^{-}$secretory flux by an equivalent fraction, but completely prevented the appearance of basolateral $\mathrm{Cl}^{-} / \mathrm{HCO}_{3}{ }^{-}$exchange and the disappearance of apical anion exchange. A likely cause of the partial effect on transepithelial $\mathrm{HCO}_{3}{ }^{-}$flux is that part of the adaptation includes stimulation of $\mathrm{HCO}_{3}{ }^{-}$absorption by the $\alpha$-intercalated cells in the $\mathrm{CCD}$, and it is possible that the added Ab's did not inhibit this effect. Tubules incubated in nonimmune sera or with Ab's against another ECM protein (collagen IV) displayed the full effect of the acid incubation on these $\mathrm{HCO}_{3}{ }^{-}$-transport processes. In the present studies we also demonstrated that in vivo acid treatment caused the localization of hensin in the ECM of the CCDs on the basal and lateral surface of intercalated cells. Because hensin is expressed in all CCD cells where it exists in intracellular vesicles (19), we performed these studies in unpermeabilized tubules incubated with anti-hensin $\mathrm{Ab}$ 's at $4^{\circ} \mathrm{C}$ to prevent endocytosis of the Ab's. Remarkably, the cells with a thick and prominent peanut lectin cap (i.e., unequivocal $\beta$ cells) had no extracellular hensin, and the cells that had newly deposited extracellular hensin had little or no apical peanut lectin. We were able, however to see a few cells that were transitional, in that they had punctate peanut lectin staining and extracellular hensin. These results in the aggregate demonstrate that the localization of hensin to the ECM is a central mediator of intercalated cell plasticity. Clearly, determination of events "upstream" of hensin, whereby acid media induce ECM localization of hensin, is an important future aim of our studies. The results presented here highlight the utility of the cell culture model in identi- fication of new genes and proteins involved in mediating complex physiological phenomena such as the plasticity of polarity of the intercalated cells.

Apical $\mathrm{Cl}^{-} / \mathrm{HCO}_{3}{ }^{-}$exchange. The molecular identity of the apical anion exchanger has been the subject of extensive investigation. Immunocytochemistry using a large number of anti-AE1 Ab's has been negative. Recent studies have identified two new candidates for apical anion exchange, $\mathrm{AE} 4$, a new member of the $\mathrm{Na}-$ $\mathrm{HCO}_{3}$ cotransporter family (35), and pendrin $(36,37)$. AE4 is present in a subpopulation of PNA-positive cells of the rabbit kidney cortex. Pendrin, located in the apical membrane of mouse, rat, and human intercalated cells, was clearly found to mediate $\mathrm{HCO}_{3}{ }^{-}$secretion, since tubules isolated from mice deleted in pendrin failed to secrete $\mathrm{HCO}_{3}^{-}$.

Intercalated cells exist in a continuum of subtype. Initially, we based our analysis of subtypes of intercalated cells on the presence of PNA, the polarized location of $\mathrm{Cl}^{-} / \mathrm{HCO}_{3}{ }^{-}$exchange, and the presence of apical endocytosis $(4,6)$. While this provided a simplified distribution of two canonical subtypes, others $(9,15,29,38)$ have shown using a variety of methods that there are more than two subtypes of intercalated cells. In a comprehensive analysis of the pattern of expression of $\mathrm{H}^{+}-$ ATPase, Bastani et al. (7) concluded that there were six subtypes of intercalated cells and that acidosis shifted the population density toward the $\alpha$ type, while alkalosis shifted it toward the $\beta$ type. Just as importantly, "intermediary types" were also observed under control conditions, implying intercalated cells with potential to change to $\alpha$ or $\beta$ type. However, population studies cannot determine whether an individual cell can change its phenotype. We showed previously (5) that acid incubation of CCDs induced $\beta$-intercalated cells to endocytose PNA from the apical membrane and sequester it in apical vesicles. Here we show that the same identified $\beta$-intercalated cells before and after a 3-hour incubation in acid media reduce the size of PNA caps and apical $\mathrm{Cl}^{-} / \mathrm{HCO}_{3}{ }^{-}$exchanger activity. Moreover, acid incubation resulted in the insertion of basolateral $\mathrm{Cl}^{-} / \mathrm{HCO}_{3}{ }^{-}$exchangers in $39 \%$ of identified $\beta$-intercalated cells; this process also required protein synthesis and intact microfilaments, but somehow proceeded despite microtubule inhibition by colchicine. When reviewing the histogram of these responses (see Figure 4), it is clear from a functional viewpoint that there is a continuum of responses, in keeping with the above-noted population studies performed after acid-base perturbations. The functional consequences of this $\beta$-intercalated cell remodeling is to reverse the polarity of $\mathrm{HCO}_{3}{ }^{-}$flux during acid treatment (see Figure 1) by removing or inactivating apical $\mathrm{Cl}^{-} / \mathrm{HCO}_{3}{ }^{-}$exchangers from the apical membrane and inserting $\mathrm{Cl}^{-} / \mathrm{HCO}_{3}{ }^{-}$exchangers on the basolateral membrane. And, from the data of Bastani et al. (7), these adapting cells sorted the $\mathrm{H}^{+}$pumps from the basolateral to the apical membranes. This process depends on the newly identified protein called hensin, 
which is synthesized and polymerized by adapting intercalated cells. Hensin has a critical role in the adaptation to acid-base disturbances: the cellular mechanisms by which it exerts its role must await the identification of its receptor.

\section{Acknowledgments}

This work was supported by NIH grants DK-20999 (to Q. Al-Awqati) and DK-50603 (to G.J. Schwartz) and by a Grant-in-Aid from the American Heart Association (0150138N, to G.J. Schwartz). The Columbia Confocal Facility is supported by NIH grant RR-10506.

1. Kaissling, B., and Kriz, W. 1979. Structural analysis of the rabbit kidney. Adv. Anat. Embryol. Cell Biol. 56:1-121.

2. Madsen, K.M., and Tisher, C.C. 1986. Structural-functional relationships along the distal nephron. Am. J. Physiol. 250:F1-F15.

3. Tsuruoka, S., and Schwartz, G.J. 1996. Adaptation of rabbit cortical collecting duct $\mathrm{HCO}_{3}{ }^{-}$transport to metabolic acidosis in vitro. J. Clin. Invest. 97:1076-1084

4. Schwartz, G.J., Barasch, J., and Al-Awqati, Q. 1985. Plasticity of functional epithelial polarity. Nature. 318:368-371.

5. Satlin, L.M., and Schwartz, G.J. 1989. Cellular remodeling of $\mathrm{HCO}_{3}{ }^{-}$secreting cells in rabbit renal collecting duct in response to an acidic environment. J. Cell Biol. 109:1279-1288.

6. Schwartz, G.J., Satlin, L.M., and Bergmann, J.E. 1988. Fluorescent characterization of collecting duct cells: a second $\mathrm{H}^{+}$-secreting type. Am.J. Physiol. 255:F1003-F1014.

7. Bastani, B., Purcell, H., Hemken, P., Trigg, D., and Gluck, S. 1991. Expression and distribution of renal vacuolar proton-translocating adenosine triphosphatase in response to chronic acid and alkali loads in the rat. $J$. Clin. Invest. 88:126-136.

8. Brown, D., Hirsch, S., and Gluck, S. 1988. An $\mathrm{H}^{+}$-ATPase in opposite plasma membrane domains in kidney epithelial cell subpopulations. Nature. 331:622-624.

9. Schuster, V.L., Fejes-Toth, G., Naray-Fejes-Toth, A., and Gluck, S. 1991. Colocalization of $\mathrm{H}^{+}$ATPase and band 3 anion exchanger in rabbit collecting duct intercalated cells. Am. J. Physiol. 260:F506-F517.

10. Satlin, L.M., Matsumoto, T., and Schwartz, G.J. 1992. Postnatal maturation of rabbit renal collecting duct. III. Peanut lectin-binding intercalated cells. Am. J. Physiol. 262:F199-F208.

11. McKinney, T.D., and Burg, M.B. 1977. Bicarbonate transport by rabbit cortical collecting tubules. J. Clin. Invest. 60:766-768.

12. Atkins, J.L., and Burg, M.B. 1985. Bicarbonate transport by isolated perfused rat collecting ducts. Am. J. Physiol. 249:F485-F489.

13. Lombard, W.E., Kokko, J.P., and Jacobson, H.R. 1983. Bicarbonate transport in cortical and outer medullary collecting tubules. Am. J. Physiol. 244:F289-F296.

14. Verlander, J.W., Madsen, K.M., Stone, D.K., and Tisher, C.C. 1994. Ultrastructural localization of $\mathrm{H}^{+}$ATPase in rabbit cortical collecting duct. J. Am. Soc. Nephrol. 4:1546-1557.

15. Schuster, V.L. 1993. Function and regulation of collecting duct intercalated cells. Annu. Rev. Physiol. 55:267-288.

16. Yasoshima, K., Satlin, L.M., and Schwartz, G.J. 1992. Adaptation of rabbit cortical collecting duct to in vitro acid incubation. Am. J. Physiol. 263:F749-F756.

17. Edwards, J.C., et al. 1992. Conditional immortalization of bicarbonatesecreting intercalated cells from rabbit. Am. J. Physiol. 263:C521-C529.

18. Hikita, C., Takito, J., Vijayakumar, S., and Al-Awqati, Q. 1999. Only mul- timeric hensin located in the extracellular matrix can induce apical endocytosis and reverse the polarity of intercalated cells. J. Biol. Chem. 274:17671-17676.

19. Takito, J., Hikita, C., and Al-Awqati, Q. 1996. Hensin, a new collecting duct protein involved in the in vitro plasticity of intercalated cell polarity. J. Clin. Invest. 98:2324-2331.

20. Tsuruoka, S., and Schwartz, G.J. 1997. Metabolic acidosis stimulates $\mathrm{H}^{+}$ secretion in the rabbit outer medullary collecting duct (inner stripe) of the kidney. J. Clin. Invest. 99:1420-1431.

21. Tsuruoka, S., Swenson, E.R., Petrovic, S., Fujimura, A., and Schwartz, G.J. 2001. Role of basolateral carbonic anhydrase in proximal tubular fluid and bicarbonate absorption. Am. J. Physiol. 280:F146-F154.

22. Schwartz, G.J., Goldsmith, D.I., and Fine, L.G. 1978. p-Aminohippurate transport in the proximal straight tubule: development and substrate stimulation. Pediatr. Res. 12:793-796.

23. Tsuruoka, S., and Schwartz, G.J. 1998. Adaptation of the outer medullary collecting duct to metabolic acidosis in vitro. Am. J. Physiol. 275:F982-F990.

24. van Adelsberg, J., Edwards, J.C., Takito, J., Kiss, B., and Al-Awqati, Q. 1994. An induced extracellular matrix protein reverses the polarity of band 3 in intercalated epithelial cells. Cell. 76:1053-1061.

25. Vijayakumar, S., Takito, J., Hikita, C., and Al-Awqati, Q. 1999. Hensin remodels the apical cytoskeleton and induces columnarization of intercalated epithelial cells: processes that resemble terminal differentiation. J. Cell Biol. 144:1057-1067.

26. Fejes-Toth, G., Naray-Fejes-Toth, A., Satlin, L.M., Mehrgut, F.M., and Schwartz, G.J. 1994. Inhibition of bicarbonate transport in peanut lectin-positive intercalated cells by a monoclonal antibody. Am. J. Physiol. 266:F901-F910.

27. Jennings, M.L., Anderson, M.P., and Monaghan, R. 1986. Monoclonal antibodies against human erythrocyte band 3 protein. Localization of proteolytic cleavage sites and stilbenedisulfonate-binding lysine residues. J. Biol. Chem. 261:9002-9010.

28. Hikita, C., et al. 2000. Induction of terminal differentiation in epithelial cells requires polymerization of hensin by galectin 3. J. Cell Biol. 151:1235-1246.

29. Weiner, I.D., Weill, A.E., and New, A.R. 1994. Distribution of $\mathrm{Cl}^{-} / \mathrm{HCO}_{3}$ exchange and intercalated cells in rabbit cortical collecting duct. Am.J. Physiol. 267:F952-F964.

30. Koeppen, B.M. 1985. Conductive properties of the rabbit outer medullary collecting duct: inner stripe. Am. J. Physiol. 248:F500-F506.

31. Verlander, J.W., Madsen, K.M., Cannon, J.K., and Tisher, C.C. 1994. Activation of acid-secreting intercalated cells in rabbit collecting duct with ammonium chloride loading. Am. J. Physiol. 266:F633-F645.

32. van Adelsberg, J., and Al-Awqati, Q. 1986. Regulation of cell $\mathrm{pH}$ by $\mathrm{Ca}^{+2}$ mediated exocytotic insertion of $\mathrm{H}^{+}$-ATPases. J. Cell Biol. 102:1638-1645.

33. Winyard, P.J.D., Bao, Q., Hughes, R.C., and Woolf, A.S. 1997. Epithelial galectin-3 during human nephrogenesis and childhood cystic diseases. J. Am. Soc. Nephrol. 8:1647-1657.

34. Takito, J., et al. 1999. Hensin, the polarity reversal protein, is encoded by DMBT1, a gene frequently deleted in malignant gliomas. Am. J. Physiol. 277:F277-F289.

35. Tsuganezawa, $\mathrm{H}$., et al. 2001. A new member of the $\mathrm{HCO}_{3}{ }^{-}$transporter superfamily is an apical anion exchanger of $\beta$-intercalated cells in the kidney. J. Biol. Chem. 276:8180-8189.

36. Royaux, I.E., et al. 2001. Pendrin, encoded by the Pendred syndrome gene, resides in the apical region of renal intercalated cells and mediates bicarbonate secretion. Proc. Natl. Acad. Sci. USA. 98:4221-4226.

37. Soleimani, M., et al. 2001. Pendrin: an apical $\mathrm{Cl}^{-} / \mathrm{OH}^{-} / \mathrm{HCO}_{3}^{-}$exchanger in the kidney cortex. Am. J. Physiol. 280:F356-F364.

38. Emmons, C., and Kurtz, I. 1994. Functional characterization of three intercalated cell subtypes in the rabbit outer cortical collecting duct. $J$. Clin. Invest. 93:417-423. 